KAIROS ELT JOURNAL, Vol. 2, No. 3, December 2018

Copyright $\odot 2018$, ISSN: 2580-4278

\title{
IMPROVING STUDENTS' READING COMPREHENSION THROUGH CONTEXT CLUES STRATEGY AT THE EIGHTH GRADE OF SMP DHARMA WANITA MEDAN
}

\author{
Apriliyanti, Karisma E. Tarigan, Jontra J. Pangaribuan \\ Catholic University of Saint Thomas
}

\begin{abstract}
Reading is one of the four language skills in English, they are listening, speaking, reading and writing. Students get bored with reading and it is very difficult for them to work with it because they do not understand how to comprehend a reading material. Thus, they need some ways or strategy which could help students's reading comprehension on narrative text. The teacher should be creative to search for interesting strategy to teach reading comprehension on narrative text. Context Clues strategy can help the students to understand a narrative text. The objectives of this study to find out the students' reading comprehension by Context Clues strategy. The subject of this study were the eighth grade students of SMP Dharma Wanita Medan. In conducting this research the writer used Classroom Action Research (CAR) as the method of research. The test was used to gather the quantitative data. Based on the finding of this study, it showed in pre-test only 3 students $(10 \%)$ who passed KKM (the Mastery Minimum Criteria), and post test 27 students (90\%). The result of this research revealed that there was a significant improvement of the students' achievement in the post test. This improvement was shown by the comparison between the mean scrore of pre-test $(47,26)$, and post test (80.33). Furthermore, the students were interested in Context Clues Strategy, it can be seen from their full attention during the teaching learning process. Therefore, Context Clues Startegy was effective strategy in helping students to improve their reading comprehension especially in narrative text.
\end{abstract}

Keywords : context clues strategy, reading comprehension, narrative text

\section{INTRODUCTION}

There are four skills in language learning process namely listening, speaking, reading, and writing. Reading is one of the important skills in English and it gives many benefits for us. Reading is the window of the world. By reading, people can get more knowledge and information from books, magazines, newspapers, and others. Reading is the most important component in learning process and sosial interaction.

Anderson (2003:68) states, "Reading is a fluent process of readers combining information from a text and their own background knowledge to build meaning". Reading is process to transfer the science from the book to the brain, from writer to reader, and this information will not be received by the readers if they do not understand what the meaning of the text is. Other problems in reading are lack of vocabularies and also pronunciation. The solutions of the problems are the teacher should know more about approaches, methods, and strategies in learning English, as the method will support the teacher's way to make his teaching more effective.

Kruidenier (2002:77) states, "Reading comprehension can be described as understanding a text that is read, or the process of constructing meaning from a text". Reading comprehension is an active process and the reader must interact. It is also a strategic process which can be taught. As comprehension takes place, words are associated with their meaning in the reader's memory and phrases and sentences are processed as clearly as possible to that the meanings derived from one word, phrase, or sentence are not lost before the next is processed.

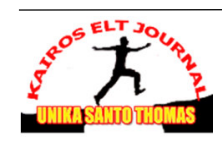


KAIROS ELT JOURNAL, Vol. 2, No. 3, December 2018

Copyright $\odot 2018$, ISSN: 2580-4278

The writer interviewed Ma'am V Ginting, SS, the teacher of English of the eighth grade students of SMP Dharma Wanita Medan. She said that many students have difficulties in comprehending English textsand they are always confused when they are reading English texts. The students also lack of motivation.

Based on the facts above, the writer chooses a strategy to solve those problems that is Context Clues Strategy. Denton (2007:201) states that context clues can give students an idea or hint for the possible mean of an unknown word might mean. The clues are found around the unknown word whether in the same sentence or in sentences before and after the sentence containing the unknown word. Thus, Context Clues Strategy gives benefit to students' competence in comprehending reading materials. In addition, Yuen (2009:5) states, "The use of context clues to gain knowledge of new words during reading". It will help the students to become an expert of reading text. The advantage of Context Clues Strategy for teachers is they will get a new knowledge about the teaching method to improve their teaching learning process and make the study more attractive. Consequently it will improve the students' motivation in reading.

There are previous researches conducted by researcher. Masyarah in (2012) who conducted a research entitled "The Effectiveness of Context Clues Strategy in Reading Comprehension at MTs ASSAFI'IYAH GONDANG". Based on the data that heen analyzed, it was found that there was an effectiveness of teaching reading after the context clues strategy was aplied. The mean score of the students' in the pretest is 50,82. After context clues strategy was applied the mean score of the students became 74,85 in the post test cycle I and in the post test cycle II the mean score of the students became 77,90. She concluded that context clues strategy is effective to teaching reading.

Based on the background of the study above the writer decided to conduct a research with the title Improving the Students' Reading Comprehension Through Context Clues Strategy At The Eighth Grade Of SMP Dharma Wanita.

\section{REVIEW OF LITERATURE Reading}

Reading is a skill essential for formal education and for an individual'ssuccess in society. According to Grabe and Stoller (2002:9) reading is the ability to draw meaning from the printed page and interpret this information appropriately. It is a process by which people gain information and ideas from the books, newspaper, letters, megazine and other materials. Reading is also a cognitive activity in which reader takes part in a conversation with the author through the text.

Snow (2002:11) states, "Reading comprehension is defined as the process of simultaneously extracting and constructing meaning through interaction and involvement with written language". The process of constructing meaning is the process in which the reader combines their prior knowledge with the additional information from a text, draws the meaning of words, and connect it to reach the clear understanding of the written text.

\section{Process of Reading}

According to Patel and Jain, (2008:113) the process of reading may be roadly classified into three stages:

1. The recognition stage.

At this stage the learner simply recognizes the graphic counterparts of the phonological items. For instance her recognize the spoken words in its written form. Difficulty at this stage depends upon the difference between the script of the learner's mother tongue and English and between the spelling conventions of two languages.

2. Structuring stage.

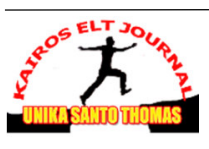


KAIROS ELT JOURNAL, Vol. 2, No. 3, December 2018

Copyright $\odot 2018$, ISSN: 2580-4278

The learner sees the syntactic relationship of the items and understands the structural meaning of the syntactical units.

3. Interpretation stage. This is the highest level in the process of reading.

Anderson (2003:70) divides the models of reading processes into three categories:

\section{Bottom-up Model}

The bottom up model typically consists of lower-l evel reading processes. Students start with the fundamental basics of letter and sound recognition, which in turn allows for morpheme recognition in what class followed by word recognition, building up to the identification of grammatical features, sentences, and longer texts. Letters, letter clusters, words, phrases, sentences, longer text, and finally meaning is the order in achieving comprehension.

\section{Top-Down Model}

The top down model, on the other hand, begins with the idea that comprehension resides in the reader. The reader uses background knowledge, makes prediction, and searches the text to confirm or reject the predictions that are made. A passage can thus be understood even if all of the individual words are not understood. Within a top-down approach to reading the teacher should focus on meaning generating activities rather than on mastery of word recognition.

\section{Interactive Model}

This third type combines elements of both bottom-up and top-down models assuming that a pattern is synthesized based on information provided simultaneously from several knowledge sources.

\section{Purposes of Reading}

Grabe and stoller (2002:13) state, there are four purposes of reading. They are:

1. Reading to search for simple information and read to skim

In reading to search, we typically scan the text for spesific piece of information or a spesific word. Reading to skim is a common part of many reading task and a useful skill is own right. It involves, in essence, a combination of strategies for guessing where important information might be in the text, and then using basic reading comprehension skills on those segments of the text until the general idea is formed.

2. Reading to learn from texts

Reading to learn typically occurs in academic and professional contexts in which a person need to learn a considerable amount of information from a text.

3. Reading to integrate information, erite and critiques texts

Reading to integrate information requires additional decision about the relative importance of complementary, mutually supporting or conflicting information and the likely restructuring of a theorical frame to accommodate information from multiple sources. These skills inevitably require critical evaluation of the information being read so that the reader can decide what information to integrate and how to integrate it for the reader's goal. In this respect, both reading to write and reading to critique text may be task variants of reading to integrate information.

4. Reading for general comprehension

The nation of general reading comprehension has been intentionally saved for last in this discussion for two reasons. First, it is the most basic purpose of reading, underlying and supporting most other purpose for readin. Second, general reading comprehension is actually more complex than commonly assumed.

\section{Types of Reading}

Petel and Jain (2008:117-123) divides reading into four types those are as follow:

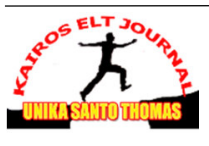


KAIROS ELT JOURNAL, Vol. 2, No. 3, December 2018

Copyright $\bigcirc 2018$, ISSN: 2580-4278

\section{Intensive Reading}

Intensive reading is related to further in language learning under the teacher's guidance. Intensive reading will provide a basic for explaining difficulties of structure and for extending knowledge of vocabulary and idioms. Intensive reading material will be the basis for classroom activity. It will not only be read but will be discussed in detail in the target language, sometimes analyzed and used as a basis for writing exercises. Intensive reading is text reading or passage reading. In this reading the learner read the text to ge knowledge or analysis. The goal of this reading is to read shorted text. This reading is done to carry out to get spesific information.

\section{Extensive Reading}

Extensive reading is used to obtain a general understanding of a subject and includes reading longer texts for pleasure. The reader wants to know about something. The reader does not care about spesific or important information after reading. Usually people read for to keep them update.

\section{Aloud Reading}

Aloud reading is basic form of classroom organization and disciplines. In reading aloud, the students are confronted with written sentences which haven't spoken before. The aim of reading aloud is the achievement or better speaking ability and the pronunciation of the students.

\section{Silent Reading}

Silent reading is a very important skill in teaching of English. This reading should be employed to increase reading ability among learners. Silent reading is done to acquire a lot of information.

According to Brown (2004:23) the types of reading are:

\section{Intensive Reading}

Intensive reading does not allow the students to find a topic they like. The topic is given by the teacher. The students also do not necessary to look for supported articles because the topic which is chosen by the teacher is usually short and easy to understand.

\section{Extensive Reading}

Extensive reading involves students reading long texts or large quantities for general understanding, with the intention of enjoying the texts. It means that students are given freedom to choose their own topic which they think are interested to be discussed. In this case, the students also have to find supported articles related to the topic in order to give them background knowledge, so that they know more about the topic they have chosen.

\section{Aloud Reading}

Aloud reading means reading a book by producing sounds audible to other. Reading aloud by the teacher can help the students in the improvement of their listening ability. Reading aloud is useful at specific moment alone. Reading aloud prevents the students from learning to understand the meaning of a sentence even when he may not know one word in the sentence.

\section{Silent Reading}

Silent reading means reading something without producing sounds audible to other. In silent reading the students can more easily work at their own material pace or speed. Silent reading must be based on student's selected text. Silent reading enables the students to read completely silently without making sounds and moving his lips. It helps him read with speed, ease and fluency.

\section{Reading Comprehension}

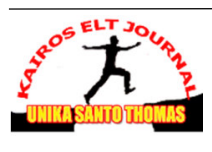


KAIROS ELT JOURNAL, Vol. 2, No. 3, December 2018

Copyright@2018, ISSN: 2580-4278

Zamelman and Hyde (1998:1) state, "Reading comprehension is a complex cognitive ability requiring the capacity to integrate text information with the knowledge of a listener or a reader and resulting in the elaboration of a mental representation". It is a multicomponent, complex process that involves many interactions between readers and what they bring to the text or background knowledge as well as variables related to the text itself (interest in text, understanding of text types). It involves a complicated process.

Goodman (1980:144) states, "Reading comprehension is mental process that occurs in the brain,it is difficult to observe, to measure, and to teach directly". Students candiscuss reading content, answer questions, and verbalize how theyarrived at answer, but the actual mental process cannot be observed. Agood way to explore the process of reading comprehension is to discussreading with a reader who shares his or her thoughts as he or she reads.

\section{Level of Comprehension}

Burn et al. (1990:177) state that there are four levels of comprehension that must be achieved in reading comprehension. The four levels of reading comprehension are identified as follows:

\section{Literal comprehension}

Literal comprehension is the skill of getting primary direct literal meaning of a word, idea, or sentence in context.

\section{Interpretive Comprehension}

Interpretive Comprehension is to identify ideal and meaning that are not explicitly stated in the written text.

\section{Critical Reading}

Critical reading is to evaluate what is read, and examine critically the thought of the writer.

\section{Creative Reading}

Creative reading is to apply ideas from the text to new situations and to recombine author's ideas with other ideas to from new concepts or to expand old ones.

Heilman (1981:13) divide reading comprehension into:

\section{Literal Comprehension}

Reading for literal comprehension is the most obvious. Comprehension at this level involves surface meanings. Reading for literal conprehension which involves acquiring information, is directly stated in a selecton. Everyone who hopes to obtain high level of reading must master literal reading at first. The ablitity to follow directions and the ability to restate author's material are skllis involved in literal reading. For example, the teacher can ask students to find information and recall main ideas that are explicitly stated in the passage or a text and selecting topic sentence and detrmining the meaning of words by context.

\section{Interpretative Comprehension}

Interpretative reading, involves reading between the lines or making inference. It is process of driving ideas that implied rather than directly stated. At this level, readers go beyond what is said and read for deeping meaning. They must be able to read critically what they have read. Reader must able to see relationship among ideas, for example: ideas go together and also see the impiled meanings of these idea. Interpretative or referential comprehension includes infering main ideas or passages in which the main ideas are not directly stated, referent pronouns, referent of adverbs, detecting the author's purpose in writing, and drawing conclusion. Reason with information presented to understand the author's tone, purpose, and attitude. Infer factual information, main ideas, comparison, cause-effect relationship not explicity stated in the passage.

\section{Critical Comprehension}

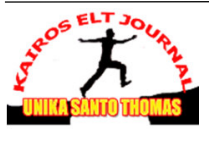


KAIROS ELT JOURNAL, Vol. 2, No. 3, December 2018

Copyright $\odot 2018$, ISSN: 2580-4278

Critical reading is evaluating written material, the ideas discovered in the material with known standarts drawing conclusions about their accuracy, appropriatness and timelines. The critical reader must be an active reader, questioning, searching for fact, and suspending judgement until he or she considered all the material. Critical reading depends upon literal comprehension and grasping ideas is especially important.

\section{Teaching Reading}

According to Richardson (2009:307) students can be taught to recognize the various kinds of context clues as well as how to read ahead and use the clues to predict, infer, and reason out meanings. They also need to understand that context can sometimes be insufficient or even misleading. Other factors need to be considered to ensure accurate comprehension. In addition to begin to understand the importance of "concepts in context," think of any word in isolation.

Graves (1986:45) states, "Using context is one strategy students can use thatcan help them to become independent word learnersand it also helps account for the words studentslearn outside of intentional instruction". In addition, Gambrell and Headley (2006:111) state, "Context can be valuable by helping to accountfor the words students learn outside of directintentional instruction, students need to know andunderstand how to use the context in order for it tobe a truly useful strategy". Knowing how to use context is one of the mostimportant skills that can be taught in order to promotereading growth in students.

\section{Narrative Text}

Alderson (2000:23) states, "Narration is any written English text in which the writer wants to amuse, entertain people, and to deal with actual or vicarious experience in different ways". Apriliawati (2009:39) states, "Narrative uses conflicts among the participants, either natural conflict, social conflict or psychological conflict. In some ways, a narrative text combines all these conflicts. Thus, commonly narrative text is found in story book".

Ayres (2008:5) states, "Narrative text is one of the forms of developing writing, for example characters told the history of something based on the development of writing from time to time". It means that a narrative text is a text which contains a story ordered chronologically. In order that the text can be enjoyed by the readers, the writer should arrange the text interestingly. The purpose of telling the story is to give meaning, and to entertain the readers.

\section{Context Clues Strategy}

According to Richardson (2009:307) students often use context clues to help determine word meanings. Sometimes, however, students are unsuccessful at using context clues because they lack a systematic strategy for figuring out unknown words. To help students develop the ability to use context to discover the meaning of unfamiliar words, teachers can discuss specific clues that they should look for in text. Kiani (2011:59) states, "Context clues have a powerful effect on students' comprehension of words and sentences. Knowledge and skill of using words in different contexts play an important role in the comprehension of new concepts, ideas and principles". It means context clues can be clear and direct the reader easily to the meaning of the word.

French (2002:58) state, "Context clues are words that surround a word or phrase the reader do not know and function as clues to get its meaning". The clues can appear before and after the unknown words. According to Karbalaei (2012:37) context clues are defined as words found around an unknown word that provides clues that reveal the meaning of the unknown word. The clues provided in the context can help students determine a word's meaning.

There are some types of context clues that can be directly taught to students.

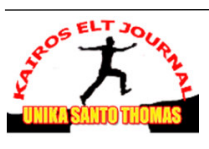


KAIROS ELT JOURNAL, Vol. 2, No. 3, December 2018

Copyright $\odot 2018$, ISSN: 2580-4278

According to Stahl (1986:662-668) there are six types of context clues:

1. Definitions: An extemporeaneous speech is one that is given on the spot without prior preparation.

2. Signal words: There are several forms of precipitation like rain, sleet, snow, and hail.

3. Direct explanations: Carl was despondent, making him feel so down hearted that he did not want to participate in anything.

4. Synonyms: When we looked into the jar we saw the larva stage, or worm, of the beetle we were studying.

5. Antonyms: Tamara was quite gregarious while her sister Mary was instead very shy.

6. Inferences: It was a good thing the locksmith only charged a nominal fee to unlock John's car because he had only a few dollars in his pocket.

According to Denton (2007:202) list them as the following table:

\section{Type of Context Clue}

Definition: The author explains the meaning of the word in the sentence or Selection.

Synonym: The author uses a word similar in meaning.

Antonym: The author uses a word nearly opposite in meaning.

Example: The author provides one or more example words or ideas.

General: The author provides several words or statements that give clues to the word's meaning.

\section{Example}

When Sara was hiking, she accidentally walked through a patch of brambles, prickly vines and shrubs, which resulted in many scratches to her legs.

Josh walked into the living room and accidentally tripped over the ottoman. He then mumbled, "I wish people would not leave the footstool right in the middle of the room. That's dangerous!

The supermarket manager complained, "Why do we have such a plethora of boxes of cereal on the shelves? In contrast, we have a real shortage of pancake and waffle mix. We've got to do a better job ordering.

There are many members of the canine family. For example, wolves, foxes, coyotes, and pets such as collies, beagles, and golden retrievers are all canines.

It was a sultry day. The day was very hot and humid. If you moved at all, you would break out in a sweat. It was one of those days to drink water and stay in shade.

\section{Procedures of Teaching Reading using Context Clues Strategy}

According to Denton (2007:203) the procedures of Context Clues Strategy in teaching reading are:

\section{Pre-Activities}

\section{Teacher's Activities}

1. Apperception: Asking some students to share what they know about report text.

2. Telling students the topic and the objective of the study.

\section{Main-Activities}

\section{Main-Activities}

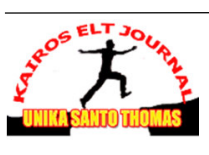

\section{Pre-Activities}

\section{Students' Activities}

1. Answering the teacher's question by telling what they know about report text.

2. Listening and paying attention.

Main-Activities 
KAIROS ELT JOURNAL, Vol. 2, No. 3, December 2018

Copyright $\odot 2018$, ISSN: 2580-4278

1. Giving a brief explanation about narrative text based on the topic chosen.

2. Showing the chart which simply lists the different types of context clues in front of the class; for example, showing it by using projector.

3. Explaining each of context clues with the sample sentences while pointing to the chart.

4. Guiding students to find meanings of unfamiliar words based on clues in the sample sentences by following the instructions of context clues technique.

5. Grouping students in partnership.

6. Giving each partnership a copy of a short report passage as a practice to find meanings of unfamiliar words based on clues in the sentences by following the instructions of context clues technique.

7. Giving each partnership a copy of chart to guide their work.

8. Circulating around the room and being available for guidance.

\section{Post-Activities}

1. Guiding students to make a brief conclusion of the lesson.

2. Evaluating the whole activities that have been done.
1. Paying attention to the teacher's explanation about narratives text based on the topic chosen.

2. Paying attention to the chart shown by the teacher and listening carefully to the teacher's explaination.

3. Paying attention to the teacher's explanation.

4. Following the instructions in using context clues technique to analyze the sample sentences with the teacher's guidance.

5. Sitting in partnership.

6. Doing the practice given by the teacher. Discussing with the partner in following the instructions of context clues technique.

7. Discussing with the partner to fill in the context clues chart.

8. Asking for the teacher's guidance if there is a difficulty while doing the practice.

\section{Post-Activities}

1. Making a brief conclusion together with the teacher.

2. Paying attention to the teacher.

According to Loucher (2001:44) the procedures of Context Clues Strategy in teaching reading are:

1. List 8-12 words on the board. Next to the word, in parentheses, write the page number, paragraph number, column number, or any other designation that will help students find the word in context.

2. When class begins, instruct students to copy words from the board with parenthetical information.

3. Assign students in groups of four. Make sure they move their desks together and are facing each other.

4. Explain the following rules: Each group must determine the meaning of each word based on how it is used in context. The parenthetical information helps students locate the word. Students may not use any source other than the page numbers in parentheses and their teammates.

5. As students eagerly define words, make a grid on the board: words listed on the side, team names listed across the top.

6. Begin the contests when sufficient time has passed.

7. Ask group 1 for their definition on word 1 . Write it in the corresponding grid space.

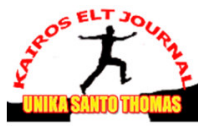


KAIROS ELT JOURNAL, Vol. 2, No. 3, December 2018

Copyright@2018, ISSN: 2580-4278

8. Ask group 2 if they agree or disagree with group 1's definition. If they agree, write 'A'. If they disagree, write 'D'. Continue until all groups have either agreed or disagreed.

9. Go over the definition. If group 1's definition is correct, they get 2 points and everybody who agreed with them gets 1 point. If group 1's definition is incorrect, everybody who disagreed with them gets 1 point.

10. Continue the game with group 2 going first, then group 3, then group 4 , etc.

\section{RESEARCH METHOD}

This research is conducted by applying Classroom Action Research (CAR). Classroom Action Research is directs toward an action or cycle of action that a researcher wants to take to address situation. In addition, Burns (2010:5) states, "Action research is research carried out in the classroom by the teacher of the course mainly with the purpose of solving a problem or improving the teaching/learning process". It means the writer must be have the solution to solve the problem and gives the improvement in the teaching process in the classroom.

The data of this research are qualitative and quantitative data. Qualitative data are obtained from the observation sheet the teacher and the students and field notes. Quantitative data are obtained from students' pre-test and post-test. In this data collection, the writer needs a collaborator. A collaborator in classroom action research is person who helps the writer to collect the data. The collaborator in this research is the teacher of English at the eighth grade students of SMP Dharma Wanita in the Academic Year of 2017/2018. She is V Ginting, SS. In this research the writer involves in the action teaching and learning process, collecting and analyzing data, also making a conclusion and report. The result of this research is the description of the process in teaching reading to the students by context clues strategy.

\section{DATA ANALYSIS AND DISCUSSION Data Analysis}

In the data analysis, there are two types of data which were analyzed to find out the result and students' responses towards learning teaching process of reading comprehension on narrative texts by using Context Clues Strategy.

\section{Discussion}

Context Clues Strategy can improve the students' reading comprehension. By Context Clues Strategy, the score of the students reading text kept increasing from the pre-test until post-test. It was proved by the data which showed the students' mean score in the pre-test, formative test, and post-test. The students' mean score in the pre-test is 47.26 , the formative test is 69.80 , and post-test is 80.33 .

From the table 4.5 showed that in the formative test the percentage of the students' who got $\geq 70$ is higher than in pre-test and also in post-tets, the percentage of the students who got score $\geq 70$ is higher than in the post-test. It means that the students' score kept increasing after Context Clues Strategy was applied in the teaching learning process. The students' responses towards learning teaching process of reading comprehension by using Context Clues Strategy can be seen in the table 4.6 In the table the students' interest, the ability of the teacher, the use of Context Clues Strategy, the students' chance in asking and the appropriateness.

\section{CONCLUSIONS AND SUGGESTIONS Conclusion}

After analyzing and discussing the data, the writer draws the following conclusion:

1. The application of Context Clues Strategy can improve the students' reading comprehension. It was found out the students' achievement of reading comprehension on narrtaive texts improved from pre-test to post-test after Context Clues Strategy was applied.

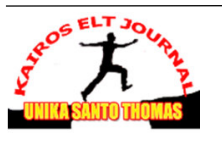


KAIROS ELT JOURNAL, Vol. 2, No. 3, December 2018

Copyright $\odot 2018$, ISSN: 2580-4278

The increase in the students' total mean score in pre-test is 47.26 , the formative test is 69.8 , and post-test is 80.33. Meanwhile, the students' score percentage who passed Mastery Minimum Criteria (Kriteria Kelulusan Minimum (KKM)) from pre-test is $10 \%$, the formative test is $46.6 \%$, and the post-test is $90 \%$, the students' score and percentage continuously increased in each test. Therefore, it is concluded that the application of Context Clues Strategy can improve the students' reading comprehension on narrative texts successfully.

2. Based on the result of field notes, observation sheets, and questionnaire, the students felt that Context Clues Strategy is very effective to help them imrove their reading comprehension on narrative text.

\section{Suggestions}

In this part, the writer would like to give some suggestions as follows:

1. The English teachers should be more active and innovative to select the teaching technique to deliver their materials. They could find a good technique to get their students' interest in learning English, especially in learning reading comprehension.

2. The students should pay attention to the rules how to improve their reading cumprehension through Context Clues Strategy.

3. The other writers, the result of this study is expected to be able to provide valuable information how to improve students' reading comprehension through Context Clues Strategy.

\section{BIBLIOGRAPHY}

Alderson, Charles. 2000. Assessing Reading. Cambridge: Cambridge University Press.

Anderson, Neil. "Reading” in Nunan, David (Ed). 2003. Practical English Language Teaching. New York: McGraw Hill.

Apriliawati, Anis. 2009. Comprehending Text Types. Bekasi: Ganesha Exact.

Ayres, Ian. 2008. Narrative Text. New York: Plenum Press.

Brown, Douglas. 2004. Language Assessment: Principles and Classroom Practices. New York: Pearson Education.

Burns, Anne. 2010. Doing Action Research in English Language Teaching: A Guide for Practitioners. London: Routledge.

Burn, Patrick. C.,et al. 1990. Teaching Reading in Today's Elementary School. Boston: Houghton Mifflin Company.

Denton, Norma. 2007. Effective Instruction in Reading for Middle School Students. Texas: Texas Education.

French, Lisa. 2002. Content-Area Reading Strategies: Social Studies. Portland: J. Weston Walch.

Gambrell. Beck. and Headley, Kei. 2006. Developing Vocabulary by Learning Words through Context: The Vocabulary-enriched Classroom: Practices for Improving the Reading performance of All Students in Grades 3 and up. New York: Scholastic.

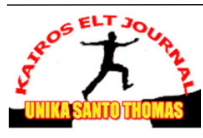


KAIROS ELT JOURNAL, Vol. 2, No. 3, December 2018

Copyright $\odot 2018$, ISSN: 2580-4278

Grabe, William and Stoller, Fredricka. 2002. Teaching and Researching Reading. London: Pearson Education.

Graves, Mayen. 1986. Vocabulary Learning and Instruction. Journal of Research in Education, 1 (3), 49-89.

Goodman, Yetta. 1980. Reading Strategies Focuus on Comprehension, NewYork: Holt, Rinehart, and Winston.

Heilman, Grue. 1981. Principles and Practice of Teaching Reading. Denver: Centennial.

Karbalaei, Ann. 2012. The Effects of Explicit Teaching of Context Clues at Undergraduate Level in EFL and ESL Context. European Journal of Natural and Social Sciences, 1 (3), 68-77.

Kiani, Niro. 2011. On the Use of Novel as a Teaching Material in EFL Classrooms: Why and How?. Journal of Economics Development \& Research, 2 (6), 283-285.

Kruidenier, John. 2002. The Principles for Adult Basic Education Reading Instruction.Washington DC: The National Institue for Literacy.

Loucher, Cross. 2001. Across the Content Areas. Alexandria: Deep Publish.

Masyarah, Fitri. 2012. The Effectiveness of Context Clues Strategy in Reading Comprehension. Sarjana's Thesis, faculty of Teachers Training and Education: University of Jember

Ngadiso, Putra. 2007. Statistics. Surakarta: State University of Surakarta.

Patel, M. F., \& Jain M, P. 2008.English Language Teaching (Method, Tools and Technique).New York: Sunrise Publisher \& Distributors.

Richadson, Judy. 2009. Reading to Learn in the Content Areas. London: Commonwealth University.

Snow, Christine. 2002. Reading for Understanding: Toward An R\&D Program in Reading Comprehension. Washington DC: Rand Corporation.

Stahl, Sig and Fairbanks, Mjun. 1986. The Effects of Vocabulary Instruction: A Model Based Meta-analysis. Journal of Educational Research, 5(6), 72-110.

Winston, Rinehart. 2000. Introduction of Research in Education. New York: Longman.

Yuen, Jong. 2009. Context Clue Detectives: Empowering Students with a Self-learning Device through the Teaching of Context Clues. Unpublished Sarjana's Thesis. University of California.

Zemelman, Daniel and Hyde Samuels. 1998. Reading Comprehension, New York: Oxford University Press. 